UDC 614.7

\title{
STUDY EXPERIENCE OF CANCER INCIDENCE AND MORTALITY IN THE COURSE OF THE SOCIAL AND HYGIENIC MONITORING IN ROSTOV REGION
}

\author{
G.T. Aydinov ${ }^{1,2}$, B.I. Marchenko ${ }^{1,3}$, Yu.A. Sinelnikova ${ }^{1}$ \\ 1 "Hygiene and Epidemiology Center in Rostov region", Russian Federation, \\ Rostov-on-Don, 67 str. $7^{\text {th }}$ line, 344019 \\ 2 "Rostov State Medical University", Russian Federation, Rostov-on-Don, 29 Nakhichevanskiy pereulok, 344022 \\ 3 “Southern Federal University", Russian Federation, Rostov-on-Don, 105/42 B. Sadovaya St., 344006
}

The article presents the results of the case follow-up of the frequency, structure and dynamics of the malignant tumors in the course of the regional social hygienic monitoring. We have considered the unified research principles and technologies of epidemiological type with the use of modern methods of retrospective analysis, prediction and the real risk assessment. It is shown that in the period 1999-2013 at the downward trend in cancer mortality in Rostov Region, the primary cancer incidence had a stable growth trend. Among the priority locations an unfavorable upward trend of the frequency of malignancies in children under 14 years old was formed, namely: malignant tumors of the esophagus, colon, rectum, melanoma of skin, breast, cervix and uterus, malignant lymphoma.

On the basis of the regional criteria risk of morbidity of the population in Rostov region, the amount of malignant tumors and cancer-related deaths within the period 1999-2013 years was assessed as moderate. The increased risk for a specified period was detected only in relation to cancer incidence in the cities of the regional subordination, among which are priority cities: Volgodonsk, Taganrog and Azov.

Key words: social hygienic monitoring, malignant tumors, epidemiological risk, assessment criteria, posthoc analysis, prognosis

Determining the complex of marker indicators with its adapation for the social and hygienic monitoring at the regional level and level of municipal structures as well as the unification of the methods of analytical studies are the current tasks during the improvement of technologies for studying the health of population. When carrying out the social and hygienic monitoring at the regional level the formation of information resources is performed in general based on the categorized data provided in the forms of the state and industry-specific reporting. The personified accounting under the most critical nosological forms is performed at the level of some municipal structures of Rostov region, together with extension of the regional list of the accounted public health indicators, that allows for using the multidimensional statistical methods, including the factorial and cluster analysis, during the analytical studies of the cause-and-effect relations.

The number of highly informative indicators of the social and hygienic monitoring system includes the malignant neoplasms (MN) morbidity that it determined both by its high social and economic significance and the significant ethiological role of the population and individual risk factors. The assessment of real (epidemiological) risk with the calculation of particular (Wi) and consolidated $(W)$ rated indicators which quantitatively characterize the probability of development of negative effects associated with the impact of the whole complex of natural and anthropogenic and technical factors is used together with traditional methods of epidemiological studies in Rosto region as the component of the categorized assessment of the pubic health condition since 2011. Herewith the real risk measure is the additional number of diseases and other negative reactions in the health of population stipulated by the excessive, compared to the background, common for the rated territories unfavorable impact of the living environment factors. The results of assessment of the real risk to the health of population represent the formal and statistical basis for the further analytical generalizations and expert hygienic evaluations both at the medical and hygienic ranking of administrative territories and for the dynamic observation purposes $[1,2]$.

The purpose of this work is to characterize the conditions and trends of oncological morbidity

(C) Aydinov G.T., Marchenko B.I., Sinelnikova Yu.A., 2015

Aydinov Gennadiy Trtdadovich - MD, professor, associate member of the International Academy of Science, ecology, safety of human and nature, Chief doctor Head of the Department of Hygiene (e-mail: master@donses.ru; tel.: +7(863) 251 04 92).

Marchenko Boris Igorevich - MD, professor, research consultant (e-mail: b.marchenko@tmei.ru; tel.: +7(634) 64-29-62).

Sinelnikova Yulia Anatolyevna - Head of the Department of the Social and Epidemiological Monitoring (e-mail: sgm@donses.ru; tel.: 8 (632) 51-04-74, 8-904-34-23-557). 
and mortality in Rostov region in relation to the middle-term forecasting and revealing the risk territories under the malignant neoplasms of priority locations. We used the representative data on the primary morbidity with malignant neoplasms of the main locations and oncological mortality provided in the annual reports No. 35 "Data on the patients with malignant neoplasms" for the 15 -year period since 1999 to 2013. The assessment of the oncological morbidity and mortality of population in Rostov region is performed using the specialized program complex Turbo oncologist, version 2.01 which implements the algorithms of epidemiologi- cal analysis of the intensity, structure, dynamics and assessment of real risk.

It is established that the average long-term level of primary oncological morbidity in Rostov region in 1999-2013 is $342.4 \%$ ооо. Herewith the frequency of malignant neoplasms among the urban population was 1.2 times more than for rural -369.2 and $306.8 \%$ ооо, respectively. The same relation is specific for the oncological mortality indicators $188.67 \%$ in general for region; for the cities $(196.0 \%$ oooo $)$ this indicator is higher than for the rural districts $(178.9 \%$ оооо by 1.1 times (table 1$)$.

Table 1

Levels, structure and dynamics of oncological morbidity and mortality of population in Rostov region during 1999-2013

\begin{tabular}{|c|c|c|c|c|c|c|c|c|c|}
\hline \multirow[b]{2}{*}{$\begin{array}{l}\text { Item } \\
\text { No. }\end{array}$} & \multirow[b]{2}{*}{$\begin{array}{l}\text { Location (form) of malignant neo- } \\
\text { plasms }\end{array}$} & \multicolumn{4}{|c|}{ Morbidity with MN } & \multicolumn{4}{|c|}{ Mortality from MN } \\
\hline & & $\%$ & $\%$ & rank & $\begin{array}{c}\text { average annual } \\
\text { rate of increase } \\
(\%)\end{array}$ & $\%$ & $\%$ & rank & $\begin{array}{l}\text { average annual } \\
\text { rate of increase } \\
(\%)\end{array}$ \\
\hline \multirow[t]{3}{*}{1} & Malignant neoplasms (total) & 342,44 & \multirow{3}{*}{100,00} & & 0,93 & 188,67 & \multirow{3}{*}{100,00} & & $-0,36$ \\
\hline & $\begin{array}{l}\text { including: } \\
\text { cities of regional subordination }\end{array}$ & 369,20 & & & 0,90 & 196,03 & & & $-0,54$ \\
\hline & rural districts & 306,84 & & & 0,93 & 178,89 & & & $-0,12$ \\
\hline 2 & $\begin{array}{l}\text { In children in the age up to } 14 \text { years } \\
\text { inclusive }\end{array}$ & 9,52 & 0,44 & & 2,86 & 3,17 & 0,28 & & $-3,12$ \\
\hline 3 & Lips & 3,11 & 0,91 & 19 & $-5,24$ & 0,56 & 0,30 & 20 & $-2,01$ \\
\hline 4 & Oral and pharyngeal cavities & 7,00 & 2,05 & 13 & $-0,12$ & 5,24 & 2,78 & 10 & $-0,53$ \\
\hline 5 & Oesophagus & 2,80 & 0,82 & 20 & 1,37 & 2,44 & 1,27 & 16 & $-0,98$ \\
\hline 6 & Stomach & 24,41 & 6,80 & 4 & $-2,10$ & 21,08 & 10,54 & 2 & $-2,72$ \\
\hline 7 & Segmented intestine & 20,46 & 5,97 & 5 & 2,50 & 12,90 & 6,84 & 4 & 0,50 \\
\hline 8 & Straight intestine, $\mathrm{PCC}$, anus & 15,78 & 4,61 & 6 & 1,69 & 11,04 & 5,91 & 5 & 0,21 \\
\hline 9 & Throat & 4,93 & 1,42 & 17 & $-0,54$ & 3,39 & 1,80 & 14 & $-2,02$ \\
\hline 10 & Trachea, bronchi, lungs & 44,51 & 12,68 & 2 & $-1,35$ & 38,43 & 19,58 & 1 & $-1,57$ \\
\hline 11 & Bones and soft tissues & 3,31 & 0,97 & 18 & $-5,81$ & 2,10 & 1,02 & 17 & $-4,12$ \\
\hline 12 & Skin melanoma & 6,03 & 1,76 & 14 & 3,51 & 2,54 & 1,40 & 15 & 3,07 \\
\hline 13 & Other malignant neoplasms of skin & 49,25 & 14,39 & 1 & 0,32 & 1,33 & 0,73 & 18 & 3,08 \\
\hline 14 & Breast & 36,68 & 10,86 & 3 & 1,49 & 18,72 & 9,76 & 3 & 0,40 \\
\hline 15 & Uterine neck & 11,39 & 3,32 & 9 & 1,87 & 5,80 & 3,14 & 7 & $-0,65$ \\
\hline 16 & Uterine body & 13,66 & 4,00 & 8 & 1,25 & 4,21 & 2,26 & 12 & 1,03 \\
\hline 17 & Ovary & 8,99 & 2,61 & 11 & 0,03 & 5,55 & 2,95 & 8 & $-2,10$ \\
\hline 18 & Prostate gland & 15,57 & 4,54 & 7 & 5,36 & 6,69 & 3,54 & 6 & 4,22 \\
\hline 19 & Bladder & 10,39 & 3,00 & 10 & 0,49 & 5,37 & 2,85 & 9 & $-2,40$ \\
\hline 20 & Thyroid gland & 5,88 & 1,72 & 15 & $-0,33$ & 0,96 & 0,50 & 19 & 0,98 \\
\hline 21 & Malignant lymphomas & 7,30 & 2,13 & 12 & 2,98 & 4,15 & 2,20 & 13 & 0,43 \\
\hline 22 & Leukemia & 5,12 & 1,49 & 16 & 0,73 & 4,28 & 2,27 & 11 & $-2,25$ \\
\hline
\end{tabular}

The first rank in the oncological morbidity structure in Rostov region is occupied by the malignant neoplasms of skin (14.4\%), the second trachea, bronchi and lungs $(12.7 \%)$, third - breast
$(10.9 \%)$, the fourth and fifth places belong to the malignant neoplasms of stomach -6.8 and $6.0 \%$ percent, respectively (table 1. fig. 1). 


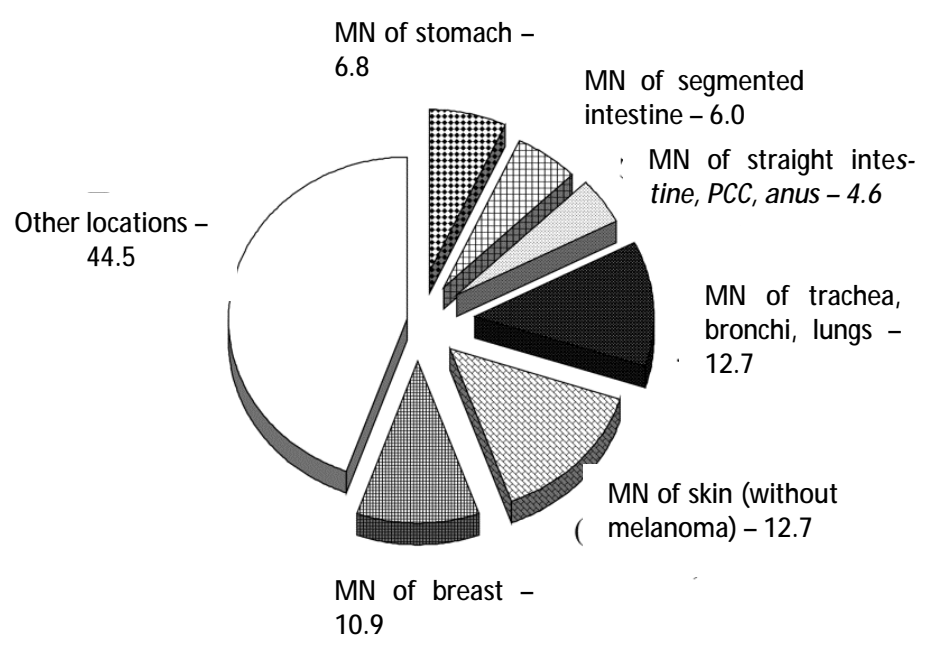

Fig. 1. The structure of oncological morbidity under the locations of process in Rostov region for 1999-2013 (\%)

The qualitative and quantitative characterization of the oncological morbidity and mortality dynamics during the social and hygienic monitoring is performed based on the trend analysis results in relation to determining the average annual rates of increase and middle-term extrapolation forecasting under the theoretical lines of trends. Thus, during the studied period the primary oncological morbidity of population in Rostov region had the stable trend to growth at the average annual rate of increase $+0.93 \%$. It is necessary to pay attention to practically equal trends to the increase of $\mathrm{MN}$ frequency in the cities and rural districts at the average annual rates of increase +0.90 and $+0.93 \%$, respectively. At the same time, the certain trend to decrease with the average annual rate of increase $-0.36 \%$ which is more expressed for urban population $(-0.54 \%)$ compared to the rural $(-0.12 \%)$ was formed in relation to the oncological mortality. The priority locations include the formation of negative trends to the increase of MN frequency in children in the age up to 14 years, $\mathrm{MN}$ of oesophagus, segmented intestine, straight intestine, PCC and anus, skin melanoma, $\mathrm{MN}$ of breast, uterine neck and body, malignant lymphomas. In our view, the apparent trend to the increase of registration of $\mathrm{MN}$ of prostate gland is stipulated primarily by the improvement of diagnostics due to the examinations for oncological markers (see table 1).

It is established that the long-term dynamics of the oncological morbidity of population in the region during 1999-2013 is more adequately described by the trend line under the exponential curve function with equation: $Y \boldsymbol{t}=\mathbf{3 1 3 , 0 8 8} X^{\mathbf{0 , 0 4 8}}$ at the correlation coefficient of $0.803(p<0.01)$ that allows for calculating the middle-term extrapolation forecasting for the next two years $358.34 \%$ oooo, respectively. It is understood that the comparison of forecasts with data obtained during the further dynamic observation can be used as the basis for assessment under the principle of inverse relationship of the efficiency of implemented preventive and recreational managerial decisions. When carrying out the social and hygienic monitoring it is necessary to execute annually the forecasts of oncological morbidity and mortality under the separate locations and administrative territories of the region (table 2, fig. 2).

The criteria assessment of oncological morbidity and mortality of population in Rostov region is performed taking into account the regional criteria which are based on the indicators of background, particular and consolidated risk calculated annually for the population of cities of regional subordination and rural districts. In order to remove the impact of differences in the sex and age structure of administrative territories on the values of regional criteria they are determined on the basis of the indirectly standardized indicators of oncological morbidity and mortality. 
Table 2

Middle-term extrapolation forecasts of oncological morbidity and mortality of population in Rostov region

\begin{tabular}{|c|c|c|c|c|c|c|c|}
\hline \multirow{2}{*}{$\begin{array}{l}\text { Item } \\
\text { No. }\end{array}$} & \multirow{2}{*}{ Administrative territory } & \multicolumn{3}{|c|}{2014} & \multicolumn{3}{|c|}{2015} \\
\hline & & $\%$ & $\Delta-0,95$ & $\Delta+0,95$ & $\%$ & $\Delta-0,95$ & $\Delta+0,95$ \\
\hline \multicolumn{8}{|c|}{ Primary morbidity with malignant neoplasms } \\
\hline \multicolumn{2}{|c|}{ Rostov region, total } & 357,31 & 351,69 & 362,92 & 358,34 & 352,72 & 363,96 \\
\hline 1 & MN of stomach & 19,33 & 18,31 & 20,35 & 18,84 & 17,82 & 19,86 \\
\hline 2 & MN of segmented intestine & 22,85 & 22,05 & 23,65 & 23,03 & 22,22 & 23,83 \\
\hline 3 & MN of trachea, bronchi, lungs & 38,69 & 37,01 & 40,37 & 38,10 & 36,42 & 39,78 \\
\hline 4 & Skin melanoma & 7,69 & 7,43 & 7,95 & 7,90 & 7,64 & 8,16 \\
\hline 5 & Other MN of skin & 49,98 & 47,82 & 52,13 & 50,02 & 47,87 & 52,18 \\
\hline 6 & MN of breast & 39,79 & 38,64 & 40,94 & 39,98 & 38,82 & 41,13 \\
\hline 7 & MN of uterine body & 15,08 & 14,16 & 15,99 & 15,25 & 14,33 & 16,16 \\
\hline 8 & MN of prostate gland & 21,81 & 21,11 & 22,51 & 22,59 & 21,89 & 23,29 \\
\hline 9 & MN of bladder & 10,52 & 10,05 & 10,98 & 10,53 & 10,07 & 11,00 \\
\hline 10 & MN of thyroid gland & 5,81 & 5,54 & 6,09 & 5,81 & 5,53 & 6,08 \\
\hline 11 & Malignant lymphomas & 8,23 & 7,94 & 8,51 & 8,29 & 8,01 & 8,57 \\
\hline 12 & Leukemias & 5,33 & 4,77 & 5,89 & 5,34 & 4,78 & 5,90 \\
\hline \multicolumn{2}{|c|}{ Cities of regional subordination } & 384,50 & 378,09 & 390,91 & 385,52 & 379,10 & 391,93 \\
\hline 1 & Azov & 496,89 & 481,21 & 512,58 & 501,73 & 486,05 & 517,41 \\
\hline 2 & Bataysk & 376,08 & 358,76 & 393,41 & 379,37 & 362,04 & 396,69 \\
\hline 3 & Volgodonsk & 394,30 & 383,91 & 404,68 & 403,95 & 393,56 & 414,33 \\
\hline 4 & Gukovo & 392,78 & 376,04 & 409,52 & 394,44 & 377,69 & 411,18 \\
\hline 5 & Donetsk & 342,10 & 316,26 & 367,94 & 339,33 & 313,49 & 365,17 \\
\hline 6 & Zverevo & 314,69 & 284,11 & 345,27 & 316,84 & 286,26 & 347,42 \\
\hline 7 & Kamensk-Shakhtinsky & 281,12 & 266,29 & 295,95 & 274,36 & 259,54 & 289,19 \\
\hline 8 & Novocherkassk & 357,42 & 331,11 & 383,73 & 360,06 & 333,75 & 386,36 \\
\hline 9 & Novoshakhtinsk & 318,35 & 292,76 & 343,94 & 320,29 & 294,70 & 345,87 \\
\hline 10 & Rostov & 371,07 & 359,30 & 382,84 & 370,58 & 358,81 & 382,35 \\
\hline 11 & Taganrog & 497,77 & 486,02 & 509,51 & 501,32 & 489,58 & 513,07 \\
\hline & Shakhty & 404,72 & 397,07 & 412,37 & 408,80 & 401,15 & 416,45 \\
\hline \multicolumn{2}{|c|}{ Rural districts of the region } & 320,22 & 314,59 & 325,85 & 321,16 & 315,52 & 326,79 \\
\hline \multicolumn{8}{|c|}{ Mortality from malignant neoplasms } \\
\hline \multicolumn{2}{|c|}{ Rostov region } & 183,17 & 177,89 & 188,45 & 182,49 & 177,21 & 187,77 \\
\hline \multicolumn{2}{|c|}{$\begin{array}{l}\text { including } \\
\text { cities of regional subord }\end{array}$} & 187,61 & 180,65 & 194,58 & 186,56 & 179,59 & 193,52 \\
\hline \multicolumn{2}{|r|}{ Rural districts of the region } & 177,14 & 173,53 & 180,76 & 176,93 & 173,31 & 180,54 \\
\hline
\end{tabular}

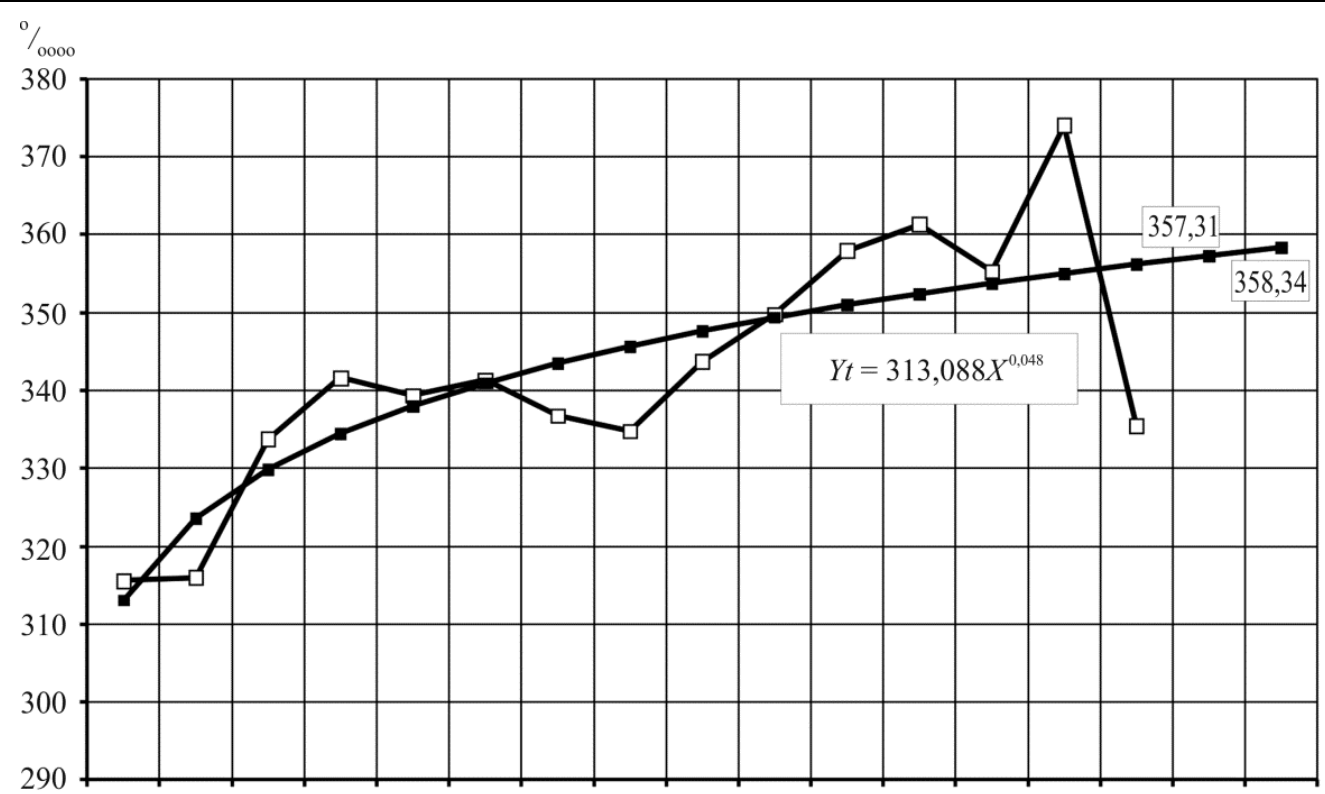

19992000200120022003200420052006200720082009201020112012201320142015 Year

Fig. 2. Dynamics, long-term trend and forecast of primary morbidity with malignant neoplesms in Rostov region (sum of locations) 
We use the regional criteria both for the dynamic observation in the system of social and hygienic monitoring (when compared to indicators under the separate territories for the reporting year) and for the hygienic ranking of territories based on the comparison to the average long-term levels of oncological morbidity and mortality (table 3 ).

Table 3

Regional criteria for assessing the oncological morbidity and mortality of population in Rostov region for 2014

\begin{tabular}{|c|c|c|}
\hline Criterial assessment of real risk & Cities of regional subordination & Rural districts of the region \\
\hline \multicolumn{3}{|c|}{ PRIMARY MORBIDITY WITH MALIGNANT NEOPLASMS } \\
\hline \multicolumn{3}{|c|}{ Based on the standard intensive morbidity indicators $(\%$ oooo $)$} \\
\hline Low & Less than 298,61 & Less than 252,32 \\
\hline Moderate & $298,61-368,62$ & $252,32-308,91$ \\
\hline Increased & $368,63-438,63$ & $308,92-365,52$ \\
\hline High & $438,64-508,65$ & $365,53-422,13$ \\
\hline Very high & 508,66 and more & 422,14 and more \\
\hline \multicolumn{3}{|c|}{ Based on the indirectly standardized morbidity indicators $(\%$ oooo $)$} \\
\hline Low & Less than 239,13 & Less than 202,26 \\
\hline Moderate & $239,13-327,38$ & $202,26-258,92$ \\
\hline Increased & $327,39-415,64$ & $258,93-315,59$ \\
\hline High & $415,65-503,90$ & $315,60-372,25$ \\
\hline Very high & 503,91 and more & 372,26 and more \\
\hline \multicolumn{3}{|c|}{ MORTALITY FROM MALIGNANT NEOPLASMS } \\
\hline \multicolumn{3}{|c|}{ Based on the standard intensive morbidity indicators $(\%$ oooo $)$} \\
\hline Low & Less than 158,61 & Less than 141,51 \\
\hline Moderate & $158,61-202,76$ & $141,51-189,91$ \\
\hline Increased & $202,77-246,91$ & $189,92-238,32$ \\
\hline High & $246,92-291,07$ & $238,33-286,73$ \\
\hline Very high & 291,08 and more & 286,74 and more \\
\hline \multicolumn{3}{|c|}{ Based on the indirectly standardized morbidity indicators $(\%$ oooo $)$} \\
\hline Low & Less than 132,44 & Less than 112,66 \\
\hline Moderate & $132,44-182,29$ & $112,66-157,28$ \\
\hline Increased & $182,30-232,15$ & $157,29-201,91$ \\
\hline High & $232,16-282,00$ & $201,92-246,54$ \\
\hline Very high & 282,01 and more & 246,55 and more \\
\hline
\end{tabular}

Based on the regional criteria the risk of morbidity for the population of Rostov region under the sum of locations of malignant neoplasms and oncological mortality during 19992013 is assessed as moderate. The increased risk during the specified long-term period is recorded only in relation to the oncological morbidity in the cities of regional subordination at the particular rated indicator $(\mathrm{Wi})$ equal to 1.01 . The use of methods for assessing the real risk allows for credible determination of the risk territories for reporting year and long-term period both in relation to the total oncological morbidity and under the separate locations and forms of process. Since the malignant neoplasms represent the heteroge- neous group of diseases which differ significantly by frequency depending on the location of process we calculate also the consolidated real risk indicators [3] under nine priority $\mathrm{MN}$ locations with contrast territorial differences (stomach; segmented intestine; straight intestine, PCC and anus; trachea, bronchi and lungs; skin; breast; prostate gland; bladder; thyroid gland). Under the results of assessment of the particular and consolidated real risk we included Vogodonsk, Taganrog and Azov from a number of cities of regional subordination to the territories of the highest risk in relation to the oncological morbidity (table 4).

Analysis of morbidity under the separate territorial points

\begin{tabular}{|c|c|c|c|c|c|c|c|}
\hline Item & Administrative territory & \multicolumn{3}{|c|}{2013} \\
\cline { 3 - 7 } No. & & $W$ & Risk & Rank & $W$ & Risk & Rank \\
\hline
\end{tabular}




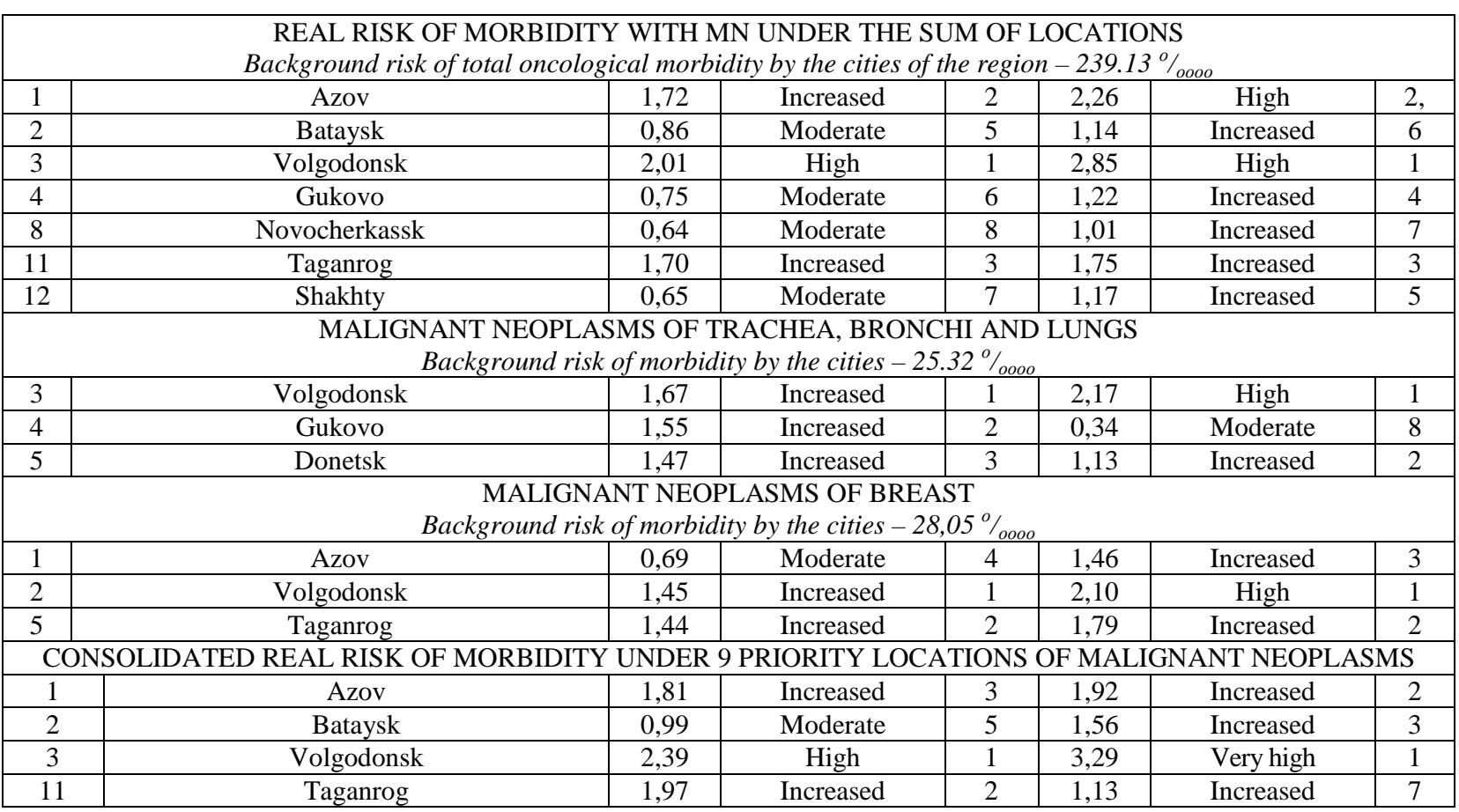

The results of assessment of real (epidemiological) risk to the health of population are considered as the formal and statistical basis for the fur-

ther analytical generalizations and expert hygienic evaluations.

\section{References}

1. Egorova I.P., Marchenko B.I. Ocenka jepidemiologicheskogo riska zdoro-v'ju na populjacionnom urovne pri mediko-gigienicheskom ranzhirovanii territorij: posobie dlja vrachej [Evaluation of epidemiological risk to health on the population level at the medical and hygienic ranging of the areas: guide for physicians]. Utverzhdeno sekciej po gigiene uchenogo soveta Minzdrava RF 24.12.1999 goda, protokol № 9. Moscow, 1999, 48 p.

2. Egorova I.P., Marchenko B.I. Metodologicheskie principy rascheta fono-vyh urovnej pri ocenke real'nogo riska dlja zdorov'ja na populjacionnom urovne [Methodological principles of the calculation of ambient levels in assessing the real risk to health on the population level]. Social'no-gigienicheskij monitoring - praktika primenenija $i$ nauchnoe obespechenie: Sb. nauchnyh trudov Federal'nogo nauchnogo centra gigieny imeni F.F. Jerismana. Moscow, 2000, part 2, pp. 225-229.

3. Egorova I.P., Marchenko B.I. Metod integral'noj ocenki sostojanija zdo-rov'ja pri vedenii social'nogigienicheskogo monitoring [The method of integral evaluation of the health status in the course of the public health monitoring]. Gigiena: proshloe, nastojashhee, budushhee: Nauchnye trudy Federal'nogo nauchnogo centra gigieny im. F.F. Jerismana. Moscow, 2001, issue 1, pp. 124-126.

4. Onishhenko G.G., Popova A.Ju., N.V. Zajceva, Maj I.V., Shur P.Z. Analiz riska zdorov'ju v zadachah sovershenstvovanija sanitarno-jepidemiologicheskogo nadzora v Rossijskoj Federacii [Health risk analysis in the tasks of improving the sanitary-epidemiological supervision in the Russian Federation]. Materialy Vse-rossijskoj nauchno-prakticheskoj konferencii s mezhdunarodnym uchasti-em. Perm', 2014, p. 42. 